\title{
Histopathological Features of Dental Pulp in Teeth with Different Levels of Chronic Periodontitis Severity
}

\author{
Elizangela Partata Zuza, Ana Luiza Vanzato Carrareto, Raphael Carlos Comelli Lia, \\ Juliana Rico Pires, and Benedicto Egbert Corrêa de Toledo
}

Department of Master of Dental Science, School of Dentistry, Educational Foundation of Barretos (UNIFEB), Avenida Roberto Frade Monte, 389, 14783-226 Barretos, SP, Brazil

Correspondence should be addressed to Elizangela Partata Zuza, elizangelazuza@yahoo.com.br

Received 28 December 2011; Accepted 10 February 2012

Academic Editors: M. Del Fabbro, I. Magnusson, C. Poh, and D. Wray

Copyright ( $) 2012$ Elizangela Partata Zuza et al. This is an open access article distributed under the Creative Commons Attribution License, which permits unrestricted use, distribution, and reproduction in any medium, provided the original work is properly cited.

Purpose. To evaluate the histopathological condition of the pulp in teeth with different levels of chronic periodontitis in humans. Methods. Twenty-five single-root nondecayed teeth were divided into three groups as follows: group 1, clinical attachment level (CAL) 3 to $4 \mathrm{~mm}$ and alveolar bone loss (BL) from 4 to $6 \mathrm{~mm}$ without reaching the tooth apex; group 2, CAL $\geq 5 \mathrm{~mm}$ and $\mathrm{BL}>6 \mathrm{~mm}$ without reaching the tooth apex; group $3, \mathrm{CAL} \geq 5 \mathrm{~mm}$ and $\mathrm{BL}>6 \mathrm{~mm}$ up to the tooth apex. Histological analyses were accomplished after laboratorial processing. Results. The mean of CAL was $3.2 \pm 0.7 \mathrm{~mm}$ in group 1, $7.6 \pm 2.0 \mathrm{~mm}$ in group 2 , and $12.1 \pm 2.8 \mathrm{~mm}$ in group 3, while for BL it was $4.8 \pm 0.9 \mathrm{~mm}, 7.6 \pm 2.2 \mathrm{~mm}$, and $11.9 \pm 2.1 \mathrm{~mm}$, respectively. Histopathological data in the pulpal chambers were similar among the three groups showing normal aspects, and, the radicular pulps showed variable levels of reactive dentin, fibrosis, dystrophic mineralizations, atrophy, and mononuclear inflammatory infiltrate. Conclusions. Gradual progression of the chronic periodontitis led to changes in the histopathological aspects of the radicular pulp with progressive involvement.

\section{Introduction}

There are communications between the pulpal tissues and the periodontal structures $[1,2]$. Some reports showed the effects of pulpal alterations on the periodontium [3-5]; however, few studies evaluated the influence of periodontitis upon pulpal tissues [3]. The microbiota of both lesions seems to be similar, but the developments of models are needed for better histological and clinical investigation [6-8].

The influence of the periodontitis upon pulpal tissues happens not only when there is a tooth apex involvement $[9,10]$, but also in cases that the periodontitis does not reach the tooth apex $[11,12]$. Radicular dentin of teeth with periodontitis can be invaded by putative periodontal pathogens, such as Prevotella intermedia, Phorphyromonas gingivalis, Fusobacterium nucleatum, Bacteroides forsythus, Peptostreptococcus micros, and Streotococcus intermedius [13].

Previous studies $[14,15]$ have also demonstrated that the bacterial invasion can occur in the root cementum and radicular dentin of those teeth with periodontal involvement, and bacteria were detected on the pulpal wall and in dental pulp of those teeth, which shows the influence of the periodontitis upon pulpal tissues. There is a scarceness of histological studies that have assessed the influence of different degrees of periodontitis upon the pulp tissue. Thus, the aim of this study was to evaluate the pulpal histopathological conditions in teeth with different levels of chronic periodontitis in humans.

\section{Materials and Methods}

The present study was approved by the Ethics Committee of the Educational Foundation of Barretos (protocol no. 02/13/11/2007). Patients were included in the study after signing an informed consent form. Thirty-seven single-root teeth indicated for extraction were evaluated in 16 patients ( 8 of each gender; mean age of 43.2 years), who sought treatment at dental clinics of UNIFEB. The teeth showed clinical features of chronic periodontitis, but with no signs 
TABLE 1: Groups and criteria for the study.

\begin{tabular}{lcc}
\hline Groups & $\begin{array}{c}\text { Number of } \\
\text { teeth }\end{array}$ & \multicolumn{1}{c}{ Criteria } \\
\hline $\begin{array}{l}\text { Group 1: moderate } \\
\text { periodontitis }\end{array}$ & 5 & $\begin{array}{c}3 \text { to } 4 \text { mm of attachment } \\
\text { and radiographic bone level } \\
\text { loss }(4 \text { to } 6 \mathrm{~mm}) \text { without } \\
\text { reaching the apex }\end{array}$ \\
\hline $\begin{array}{l}\text { Group 2: severe } \\
\text { periodontitis }\end{array}$ & 10 & $\begin{array}{c}\geq 5 \mathrm{~mm} \text { of attachment and } \\
\text { radiographic bone level loss } \\
(>6 \mathrm{~mm}) \text { without reaching } \\
\text { the apex }\end{array}$ \\
\hline $\begin{array}{l}\text { Group 3: serious } \\
\text { periodontitis }\end{array}$ & 10 & $\begin{array}{c}\geq 5 \mathrm{~mm} \text { attachment and } \\
\text { radiographic bone level loss } \\
(>6 \mathrm{~mm}) \text { reaching the apex }\end{array}$ \\
\hline
\end{tabular}

of caries, abrasions, erosions, attritions, or restorations. They also should not have been submitted to periodontal therapy in the last 6 months. Of the 37 teeth extracted, 25 of them were included in the study and 12 were discarded for presenting initial caries lesions, small composite restorations, erosions, or abrasions.

2.1. Periodontal Evaluation. The periodontal parameters were evaluated, as follows: probing depth (PD); gingival recession (GR); clinical attachment level (CAL) [16]; extension of alveolar crest bone loss (BL). The PD was defined as the distance from the gingival margin to the base of the sulcus or periodontal pocket. GR was pointed out as the distance from cementoenamel junction and the most apical point of the gingival margin. CAL was considered as the distance from the cementoenamel junction to the base of the sulcus or periodontal pocket. BL was defined as the distance from the cementoenamel junction to the most coronal point of bone crest. The periodontal measurements of PD, GR, and CAL were recorded at six sites on each tooth (distobuccal, buccal, mesiobuccal, distolingual, lingual, and mesiolingual) by means of a type-Williams periodontal probe (Hu-Friedy PCPN115BR). The assessment of BL was carried out in radiographs taken by the parallelism periapical technique by means of a precision pachymeter, with an appropriate light box in a dark environment.

The teeth were divided into three groups considering CAL parameters [17] and BL criteria, as follows: group 1, moderate periodontitis with clinical attachment level (CAL) 3 to $4 \mathrm{~mm}$ and alveolar crest bone loss (BL) from 4 to $6 \mathrm{~mm}$ without reaching the tooth apex; group 2, severe periodontitis with $\mathrm{CAL} \geq 5 \mathrm{~mm}$ and $\mathrm{BL}>6 \mathrm{~mm}$ without reaching the tooth apex; group 3 , serious periodontitis with $\mathrm{CAL} \geq 5 \mathrm{~mm}$ and $\mathrm{BL}>6 \mathrm{~mm}$ up to the tooth apex (Table 1 ). Each tooth showed at least 4 points with periodontal involvement to be included in each group.

2.2. Histological Evaluation. After exodontics, the teeth were superficially cleaned with saline solution $(0.9 \% \mathrm{NaCl})$ and the pulpal chamber was perforated for exposure. The teeth were kept in plastic containers and immersed into Buffered Formol ( $\mathrm{pH}$ 7.4) for fixation. Later, they were decalcified
TABLE 2: Clinical results in the different experimental groups.

\begin{tabular}{|c|c|c|c|c|}
\hline $\begin{array}{l}\text { Clinical } \\
\text { parameters }\end{array}$ & Group 1 & Group 2 & Group 3 & Values of $P$ \\
\hline \multirow{3}{*}{$\mathrm{GR}(\mathrm{mm})$} & \multirow{3}{*}{$2.9 \pm 1.2$} & \multirow{3}{*}{$4.6 \pm 1.0$} & \multirow{3}{*}{$6.0 \pm 2.2$} & $P_{1 \times 2}=\mathrm{NS}$ \\
\hline & & & & $P_{1 \times 3} \leq 0.05$ \\
\hline & & & & $P_{2 \times 3}=\mathrm{NS}$ \\
\hline \multirow{3}{*}{$\mathrm{PD}(\mathrm{mm})$} & \multirow{3}{*}{$1.6 \pm 0.6$} & \multirow{3}{*}{$3.4 \pm 1.7$} & \multirow{3}{*}{$6.0 \pm 2.9$} & $P_{1 \times 2}=\mathrm{NS}$ \\
\hline & & & & $P_{1 \times 3} \leq 0.05$ \\
\hline & & & & $P_{2 \times 3}=\mathrm{NS}$ \\
\hline \multirow{3}{*}{$\mathrm{CAL}(\mathrm{mm})$} & \multirow{3}{*}{$3.2 \pm 0.7$} & \multirow{3}{*}{$7.6 \pm 2.0$} & \multirow{3}{*}{$12.1 \pm 2.8$} & $P_{1 \times 2}=\mathrm{NS}$ \\
\hline & & & & $P_{1 \times 3} \leq 0.05$ \\
\hline & & & & $P_{2 \times 3} \leq 0.05$ \\
\hline \multirow{3}{*}{$\mathrm{BL}(\mathrm{mm})$} & \multirow{3}{*}{$6.3 \pm 2.0$} & \multirow{3}{*}{$7.6 \pm 2.2$} & \multirow{3}{*}{$11.9 \pm 2.1$} & $P_{1 \times 2}=\mathrm{NS}$ \\
\hline & & & & $P_{1 \times 3} \leq 0.05$ \\
\hline & & & & $P_{2 \times 3} \leq 0.05$ \\
\hline
\end{tabular}

mm: millimeters; GR: gingival recession; PD: probing depth; CAL: clinical attachment level; BL: bone lost; NS: nonsignificant $(P>0.05$, Kruskal-Wallis Test).

and submitted to the laboratorial protocol for semisequenced sections of $5 \mu \mathrm{m}$ in buccal/lingual direction, as well as dyeing with hematoxylin and eosin. Histological assessment of the specimens was performed to evaluate structural aspects of dental pulp, such as presence of reactive dentin, fibrosis, dystrophic mineralizations, atrophy, and mononuclear inflammatory infiltrate.

\section{Results}

3.1. Periodontal Clinical Data. The group with serious periodontitis (group 3) showed the highest measures of CAL and BL compared to the other groups $(P<0.05)$, whereas groups 1 (moderate periodontitis) and 2 (severe periodontitis) did not show significant differences between each other $(P>0.05)$. There were no significant differences in the GR and PD parameters between groups 1 and 2 and also between groups 2 and $3(P>0.05)$; nevertheless, a significant difference was verified between groups 1 and 3 $(P<0.05)$. Periodontal clinical data are shown in Table 2.

\subsection{Histological Aspects}

Group 1. The coronal portion of the pulp of all teeth showed loose connective tissue of normal appearance, with predominance of fibroblasts, collagen, dentin, predentin, and odontoblastic layer (Figure 1(a)). The root portion revealed reduction of the pulp canal space due to an appositional increment of reactive dentin following a repair pattern, with a decrease in the number and size of the odontoblasts. Reactive dentin showed an irregular pattern, characterized by the arrangement of dentinal tubules with odontoblastic prolongment and variations in the globular mineralization. The connective tissue of the radicular pulp revealed an increment in the collagen evolution, and some needleshaped elongated and discretely diffuse mineralization were verified in some specimens (Figure 1(b)). 

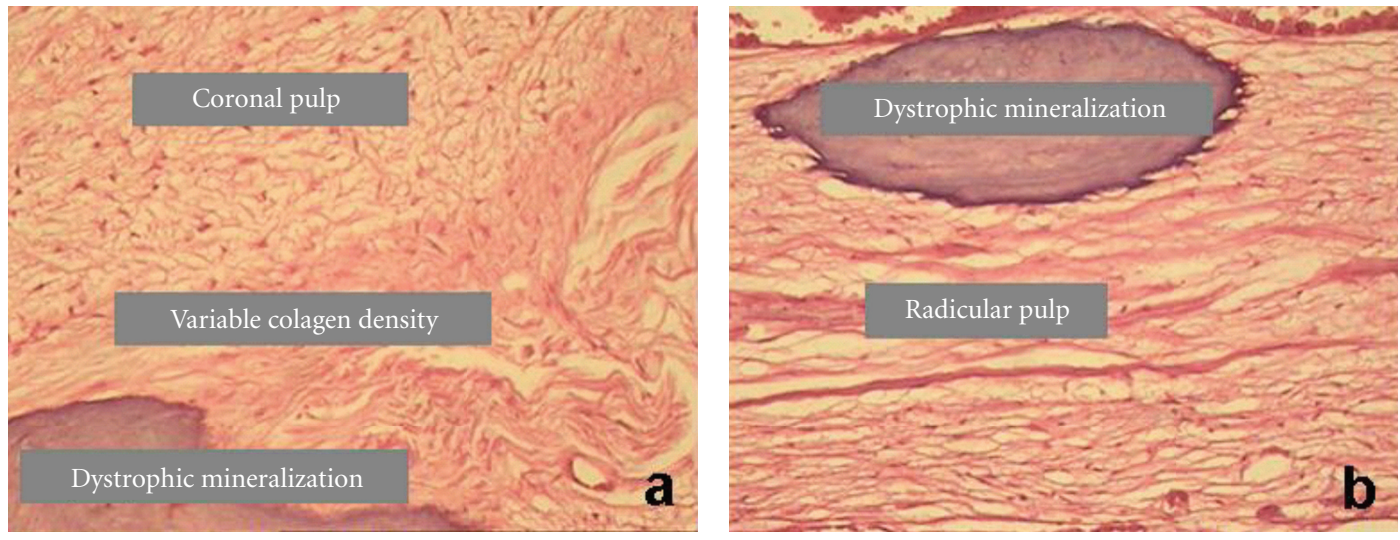

FIGURE 1: Histological aspects of (a) coronal pulp and (b) radicular pulp in group 1.

Group 2. The coronal portion of the pulp showed similar aspects to group 1 (Figure 2(c)). Reactive dentin in a more repairing and irregular pattern was verified in the root pulp, with little canalicular arrangement and decrease in the number and size of underlying odontoblasts. There was a predominance of collagen fibers bundles arranged in the connective tissue, with fibroblasts and fibrocytes. Dystrophic mineralization was observed along the root canal. Inflammatory infiltrate was observed with mononuclear cell predominance in the connective tissue of the root pulp (Figure 2(d)).

Group 3. The aspects of coronal pulp were not different from those observed in groups 1 and 2 (Figure 3(e)). Pulpal fibrosis represented by a great amount of collagen fibers and less cellularity was verified in the root pulp (Figure 3(f)). Reactive dentin pattern revealed varied levels, showing irregularities in the arrangement of canaliculi and mineralization, as well as pulp atrophy. Dystrophic mineralization was verified along the root canal, showing as elongated, scattered, nodular, and irregular amorphous structures. Some specimens showed internal resorption. Inflammatory infiltrate showed predominance of mononuclear cells (lymphocytes, plasmocytes, and macrophages) and a varying number of polymorphonuclear leukocytes. Some specimens revealed angioblastic proliferation with agglomeration of plasmocytes (Figures 3(g) and 3(h)).

\section{Discussion}

Our histological results revealed that the coronal pulp showed normal aspects in the three groups, while radicular pulp presented a gradual increasing in histological changes. Histological studies [18-22] confirmed that pulpal alterations can occur in the cases of periodontitis, with dystrophic calcification, atrophy, cell number reduction, fibrosis, repair dentin formation, inflammation, degeneration, and pulpal tissue necrosis. Some findings have also shown a significant increase in the amount of dentin formed in teeth with periodontal involvement compared to healthy teeth $[19,23$, $24]$.
A histological study [10] showed that pulpal alterations occurred more frequently in the apical region in teeth with periodontal involvement reaching the tooth apex, while the coronal pulps showed normal features. It could be suggested that the period of progression of the periodontitis may be an important factor to promote pulpal alterations, since chronic periodontitis features a slower and long-lasting development. Furthermore, it was verified fibrosis, secondary dentin, atrophy, dystrophic calcification, and inflammatory infiltrate, which occurred more frequently in the apical region of root pulp.

Our findings showed that the pulpal changes occurred only in the radicular pulp and not in the coronal pulp, in agreement with some studies [10,18-21]. Other authors [22] have also verified pathological alteration in the pulpal tissue, but a total degeneration was verified only when the circulatory pathway of the main canal was affected. Additionally, single-root teeth with periapical lesions were significantly correlated with deeper periodontal pockets and greater radiographic bone loss [25], which also confirms our results that showed greater clinical attachment loss and greater alveolar bone loss in the group with serious periodontitis reaching the tooth apex.

Conversely, other studies [26] did not find pulpal alterations even in cases of periodontitis reaching the tooth apex. This is in line with other studies $[27,28]$ that did not find correlation between the severity of periodontitis and the morphological alterations in the pulp tissue. Czarnecki and Schilder [27] verified that pulps of the teeth with periodontitis showed normal histological aspects, regardless of periodontal disease severity. Mazur and Massler [29] reported that the periodontal disease does not affect the pulp, suggesting that the pulpal degeneration was related to systemic factors. Bergenholtz and Lindhe [30] verified in monkeys that although $30 \%$ to $40 \%$ of the teeth presented clinical attachment loss, $70 \%$ of the roots showed no pulpal pathological alterations.

The influence of the pulp on the periodontal structures is more evident than the influence of periodontitis on the pulp tissue [31]; however, a chronic-degenerative reaction and asymptomatic pulpal necrosis may occur when a frequent stimulus with low intensity and long lasting was applied [32]. 

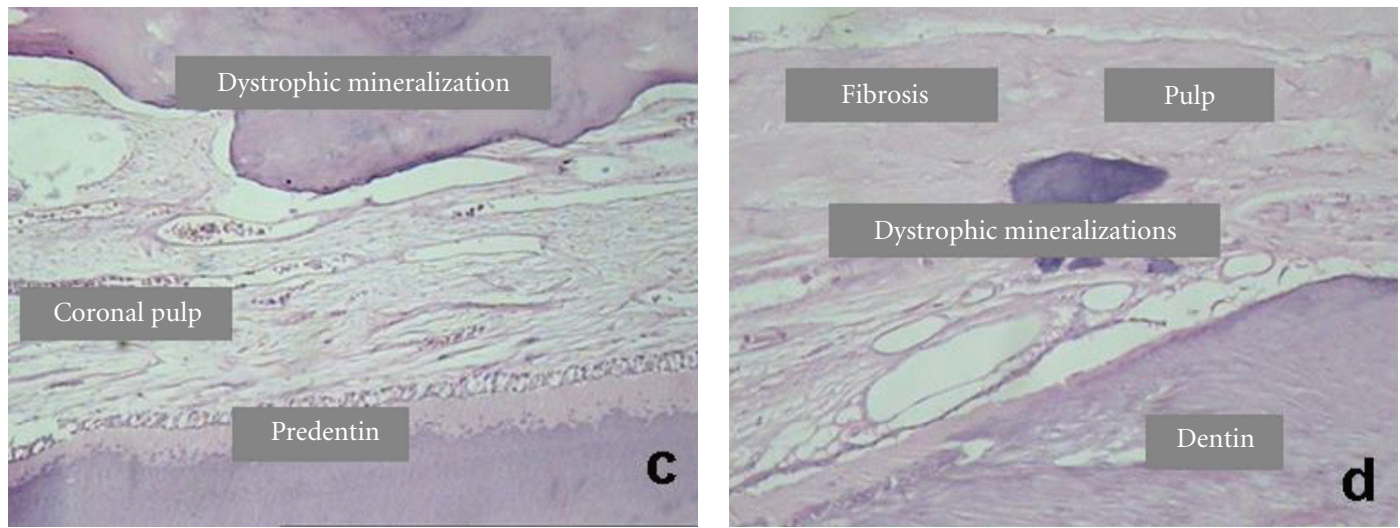

FIGURE 2: Histological aspects of (c) coronal pulp and (d) radicular pulp in group 2.
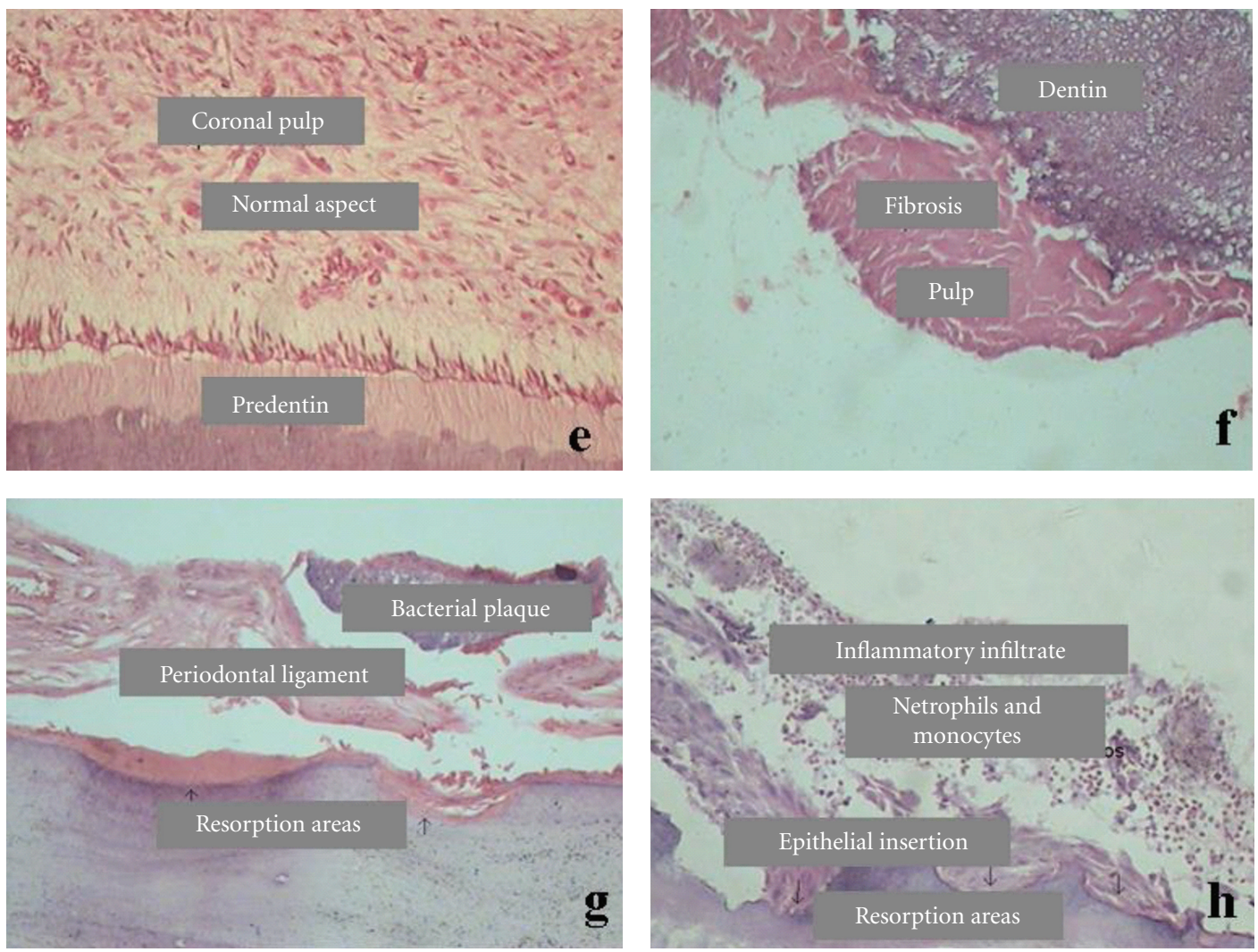

Figure 3: Histological aspects in group 3. (e) Coronal pulp, (f) radicular pulp with fibrosis, (g) resorption areas and breakdown of the periodontal ligament and (h) inflammatory infiltrate and resorption areas.

There is a scarceness of studies describing the histological features in healthy dental pulp in the different ages [10]. Histological observations of the influence of periodontitis on dental pulp must be added to current clinical studies [3335]. Thus, further studies are suggested to clarify the complex relationship between the pulp and the periodontium.

\section{Conclusions}

Within the limits of this study, it was possible to conclude that a gradual progression of the chronic periodontitis led to changes in the histopathological features of the radicular pulp with progressive involvement, but not in the pulp chamber.

\section{Conflict of Interests}

The authors declare that they have no conflict of interests.

\section{References}

[1] G. L. Pilatti and B. E. C. Toledo, "As comunicações anatômicas entre polpa e periodonto e suas conseqüências na etiopatogenia das lesões endo-periodontais," Revista Paulista de Odontologia, vol. 22, pp. 38-43, 2000 (Portuguese). 
[2] E. P. Zuza, B. E. C. Toledo, S. Hetem, L. C. Spolidório, A. J. D. Mendes, and E. P. Rosetti, "Prevalence of different types of accessory canals in the furcation area of third molars," Journal of Periodontology, vol. 77, no. 10, pp. 1755-1761, 2006.

[3] C. Solomon, H. Chalfin, M. Kellert, and P. Weseley, "The endodontic-periodontal lesion: a rational approach to treatment," The Journal of the American Dental Association, vol. 126, no. 4, pp. 473-479, 1995.

[4] B. F. Paul and J. W. Hutter, "The endodontic-periodontal continuum revisited: new insights into etiology, diagnosis and treatment," Journal of the American Dental Association, vol. 128, no. 11, pp. 1541-1548, 1997.

[5] H. X. Meng, "Periodontic-endodontic lesions," Annals of Periodontology, vol. 4, no. 1, pp. 84-90, 1999.

[6] A. Kipioti, M. Nakou, N. Legakis, and F. Mitsis, "Microbiological findings of infected root canals and adjacent periodontal pockets in teeth with advanced periodontitis," Oral Surgery Oral Medicine and Oral Pathology, vol. 58, no. 2, pp. 213-220, 1984.

[7] T. Kobayashi, A. Hayashi, R. Yoshikawa, K. Okuda, and K. Hara, "The microbial flora from root canals and periodontal pockets of non-vital teeth associated with advanced periodontitis," International Endodontic Journal, vol. 23, no. 2, pp. 100 $106,1990$.

[8] H. Kurihara, Y. Kobayashi, I. A. Francisco, O. Isoshima, A. Nagai, and Y. Murayama, "A microbiological and immunological study of endodontic-periodontic lesions," Journal of Endodontics, vol. 21, no. 12, pp. 617-621, 1995.

[9] R. S. Hirsch and N. G. Clarke, "Pulpal disease and bursts of periodontal attachment loss," International Endodontic Journal, vol. 26, no. 6, pp. 362-368, 1993.

[10] T. R. S Aguiar, Estudo histopatológico da Polpa de Dentes Humanos Portadores de Doença Periodontal Envolvendo o Ápice Radicular, Ph.D. thesis, Faculdade de Odontologia da Universidade de São Paulo, Bauru, São Paulo, Brazil, 1999.

[11] M. Zehnder, S. I. Gold, and G. Hasselgren, "Pathologic interactions in pulpal and periodontal tissues," Journal of Clinical Periodontology, vol. 29, no. 8, pp. 663-671, 2002.

[12] G. Bergenholtz and G. Hasselgren, "Endodontia e periodontia," in Tratado de Periodontologia Clínica e Implantologia Oral, J. Lindhe, T. Karring, and N. P. Lang, Eds., pp. 309-41, Rio de Janeiro, Brazil, 4th edition, 2005.

[13] G. Giuliana, P. Ammatuna, G. Pizzo, F. Capone, and M. D'Angelo, "Occurrence of invading bacteria in radicular dentin of periodontally diseased teeth: microbiological findings," Journal of Clinical Periodontology, vol. 24, no. 7, pp. 478485, 1997.

[14] P. A. Adriaens, C. A. Edwards, J. A. De Boever, and W. J. Loesche, "Ultrastructural observations on bacterial invasion in cementum and radicular dentin of periodontally diseased human teeth," Journal of Periodontology, vol. 59, no. 8, pp. 493-503, 1988.

[15] P. A. Adriaens, "Bacterial invasion in periodontitis, is it important in periodontal treatment?" Revue Belge de Medecine Dentaire, vol. 44, no. 2, pp. 9-30, 1989.

[16] G. C. Armitage, "The complete periodontal examination," Periodontology 2000, vol. 34, pp. 22-33, 2004.

[17] T. F. Flemmig, "Periodontitis," Annals of Periodontology, vol. 4, no. 1, pp. 32-38, 1999.

[18] W. C. Rubach and D. F. Mitchell, "Periodontal disease, accessory canals and pulp pathosis," The Journal of Periodontology, vol. 36, pp. 34-38, 1965.
[19] S. Seltzer, I. B. Bender, and M. Ziontz, "The interrelationship of pulp and periodontal disease," Oral Surgery, Oral Medicine, Oral Pathology, vol. 16, no. 12, pp. 1474-1490, 1963.

[20] S. Seltzer, I. B. Bender, H. Nazimov, and I. Sinai, "Pulpitisinduced interradicular periodontal changes in experimental animals," Journal of Periodontology, vol. 38, no. 2, pp. 124-129, 1967.

[21] I. B. Bender and S. Seltzer, "The effect of periodontal disease on the pulp," Oral Surgery, Oral Medicine, Oral Pathology, vol. 33, no. 3, pp. 458-474, 1972.

[22] K. Langeland, H. Rodrigues, and W. Dowden, "Periodontal disease, bacteria, and pulpal histopathology," Oral Surgery Oral Medicine and Oral Pathology, vol. 37, no. 2, pp. 257-270, 1974.

[23] S. S. Stahl, "Pulpal response to gingival injury in adult rats," Oral Surgery, Oral Medicine, Oral Pathology, vol. 16, no. 9, pp. 1116-1119, 1963.

[24] R. L. Lantelme, S. L. Handelman, and R. J. Herbison, “Dentin formation in periodontally diseased teeth," Journal of Dental Research, vol. 55, no. 1, pp. 48-51, 1976.

[25] L. Jansson, H. Ehnevid, S. Lindskog, and L. Blomlöf, "The influence of endodontic infection on progression of marginal bone loss in periodontitis," Journal of Clinical Periodontology, vol. 22, no. 10, pp. 729-734, 1995.

[26] A. B. Hattler, D. E. Snyder, M. A. Listgarten, and W. Kemp, "The lack of pulpal pathosis in rice rats with the periodontal syndrome," Oral Surgery Oral Medicine and Oral Pathology, vol. 44, no. 6, pp. 939-948, 1977.

[27] R. T. Czarnecki and H. Schilder, "A histological evaluation of the human pulp in teeth with varying degrees of periodontal disease," Journal of Endodontics, vol. 5, no. 8, pp. 242-253, 1979.

[28] G. Bergenholtz and S. Nyman, "Endodontic complications following periodontal and prosthetic treatment of patients with advanced periodontal disease," Journal of Periodontology, vol. 55, no. 2, pp. 63-68, 1984.

[29] B. Mazur and M. Massler, "Influence of periodontal disease on the dental pulp," Oral Surgery, Oral Medicine, Oral Pathology, vol. 17 , no. 5, pp. 592-603, 1964.

[30] G. Bergenholtz and J. Lindhe, "Effect of experimentally induced marginal periodontitis and periodontal scaling on the dental pulp," Journal of Clinical Periodontology, vol. 5, no. 1, pp. 59-73, 1978.

[31] G. W. Harrington, D. R. Steiner, and W. F. Ammons, "Controvérsias em Periodontia-Endodontia," in Periodontologia 2000, P. B. Robertson and T. A. Derouen, Eds., pp. 123-130, São Paulo, Brazil, 2003.

[32] A. C. Bombana, "Quais são as atuais abordagens no diagnóstico e tratamento dos envolvimentos endoperiodontais?" in Periodontia e Implantodontia-Desmistificando a ciência, R. M. Lotufo and N. T. Lascala, Eds., pp. 307-313, São Paulo, Brazil, 1st edition, 2003.

[33] E. B. Cardon, R. C. Waickl, and C. K. Rösing, "Análise da sensibilidade pulpar em dentes com diferentes graus de perda de inserção periodontal," Revista Periodontia, vol. 17, pp. 4954, 2007 (Portuguese).

[34] B. E. C. Toledo, E. P. Zuza, A. E. F. Pontes, J. R. Pires, A. L. V Carrareto, and O. E. Aielo, "Relação entre a perda óssea periodontal e a resposta clínica da polpa dental ao estímulo térmico," Revista Periodontia, vol. 18, pp. 137-142, 2008 (Portuguese). 
[35] E. P. Zuza, B. E. C. Toledo, A. L. V Carrareto, M. M. Almeida, E. P. Rosetti, and O. E. Aielo, "Interrelação entre a doença periodontal crônica e a desposta pulpar ao estímulo; avaliação clínica e radiográfica," CIÊNCIA E CULTURARevista Científica Multidiciplinar do Centro Universitáario da FEB, vol. 4, pp. 65-71, 2009 (Portuguese). 


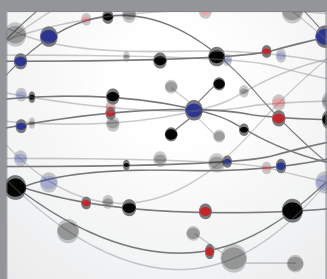

The Scientific World Journal
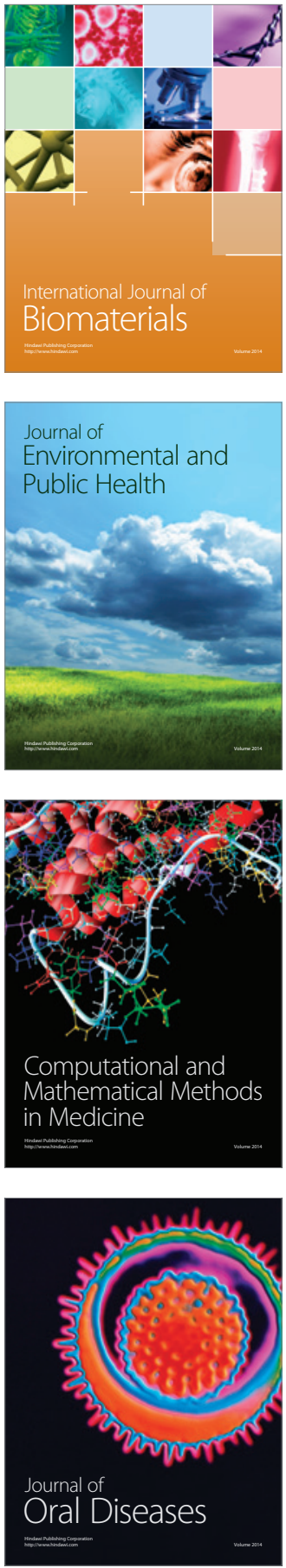
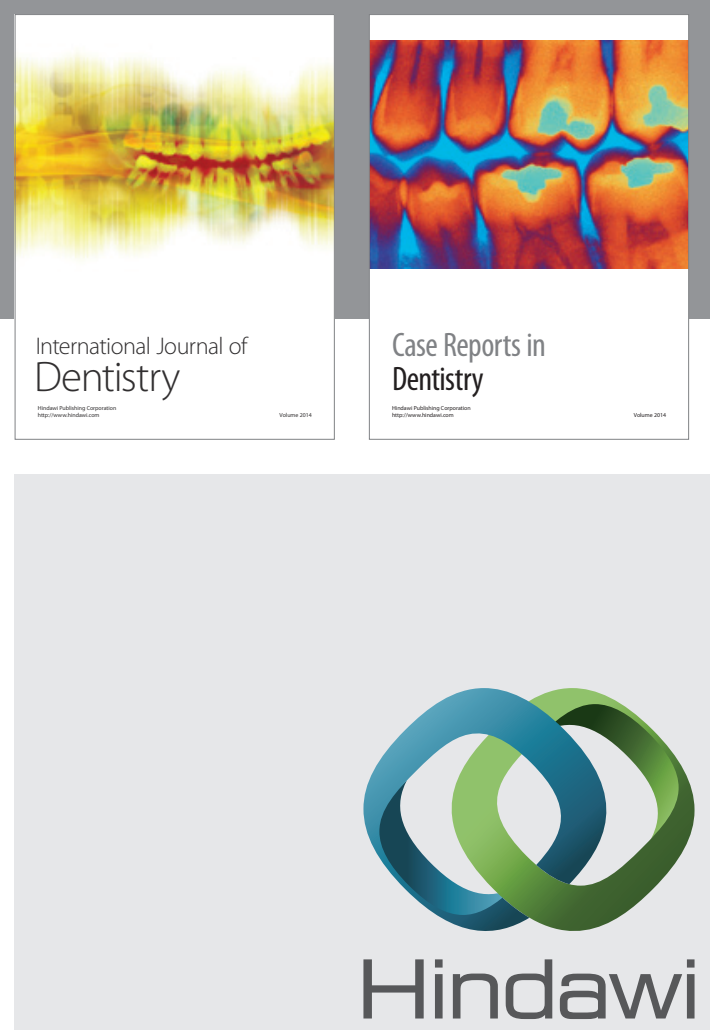

Submit your manuscripts at

http://www.hindawi.com
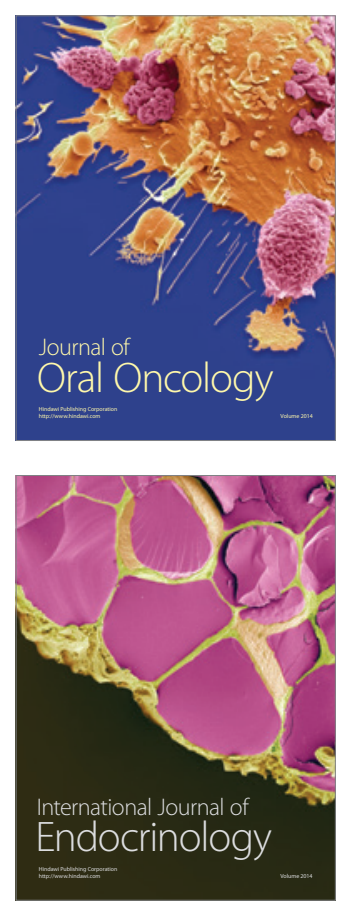
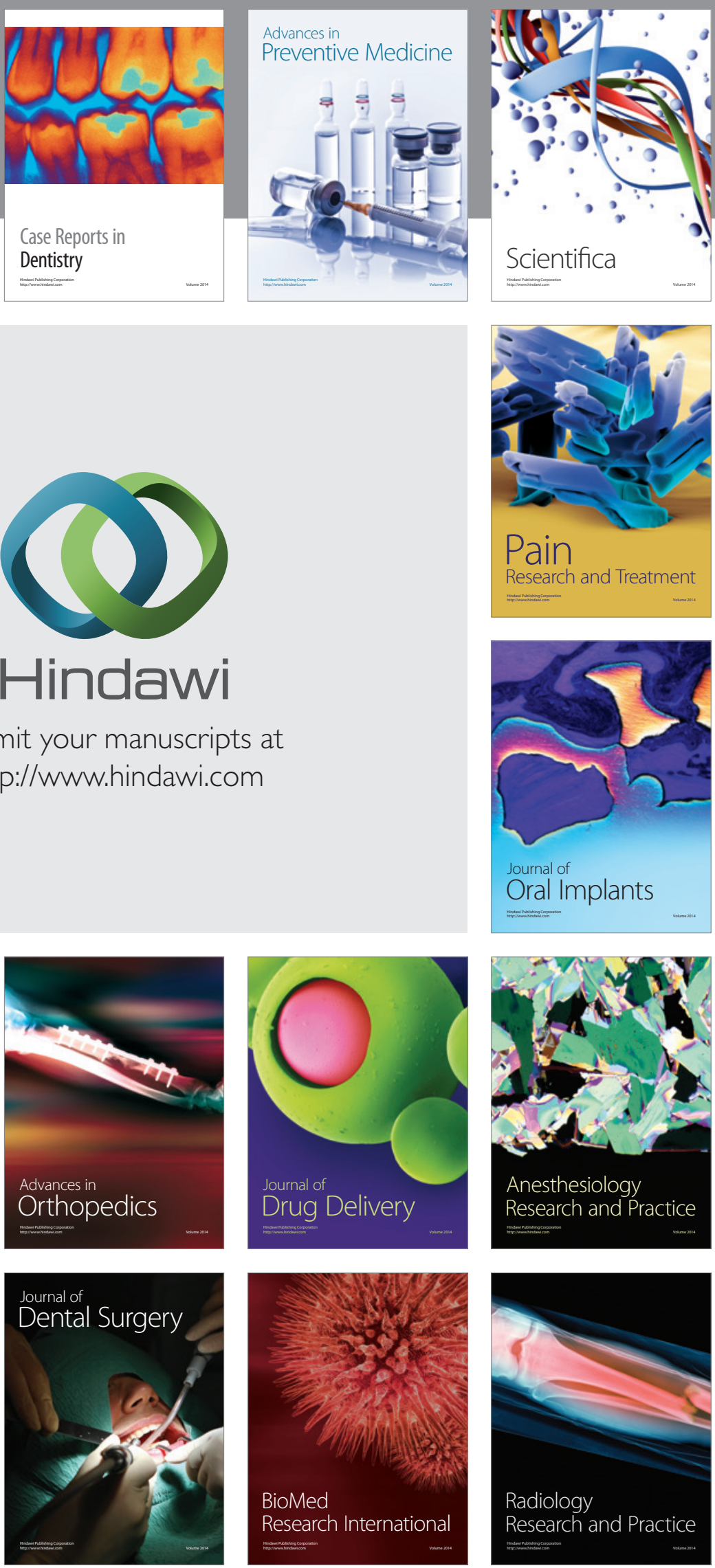